Selcuk Journal of Agriculture and Food Sciences

http://sjafs.selcuk.edu.tr/sjafs/index

Research Article
SJAFS

(2021) 35 (2), 147-154

e-ISSN: $2458-8377$

DOI:10.15316/SJAFS.2021.242

\title{
The Species and Intensities of Weed Seeds Obtained from Wheat Flour Mill Plants in Turkey ${ }^{* *}$
}

iD Neşe BOZKAN ${ }^{1}$, iD Murat KARACA ${ }^{2 *}$

${ }^{1}$ Narman District Directorate of Agriculture and Forestry, Erzurum, Turkey

${ }^{2}$ Selcuk University, Faculty of Agriculture, Department of Plant Protection, Konya, Turkey

\begin{tabular}{l}
\hline ARTICLE INFO \\
\hline Article history: \\
Received date: 16.06 .2021 \\
Accepted date: 08.07 .2021 \\
\hline
\end{tabular}

Keywords:

Weed seed

Intensity

Frequency

Flour mill plant

\begin{abstract}
Wheat production is more than $10 \%$ is in first place with potential in Konya plain of Turkey. Weed seeds mixed crop seeds cause quality and yield losses on production. This research was carried out to determine the species, intensity and frequency of weed seeds obtained from flour mill plants operating in Konya. Samples were taken from the 15 flour mill plants with working high capacity in the region. Identification of the weed seeds species in the sample was made. Comparison was made with live materials and reference documents by examining the seeds under a binocular while diagnosis of species. Also, the intensity and frequency of the species contaminated in wheat were determined. As a result of the study, 79 weed seed species belonging to 19 different families were identified. The species of families the most inclusive were Poaceae with 14 species and Leguminosae with 13 species. In order to determine intensity and frequency of species, weed seeds counted by hand, weighed in scale were recorded in laboratory. The highest weed seeds intensity as number and weight among the species were determined Galium tricornutum (rough bedstraw) with $16.16 \%$ and Aegilops cylindrica (jointed goatgrass) with $21.22 \%$ respectively. About the frequency of species, the most frequent species was Convolvulus arvensis (field bindweed) with $100 \%$.
\end{abstract}

\section{Introduction}

Wheat is a crop plant which is essential for whole humanity. Many products are made from wheat today. Wheat means being full. The role and importance of flour obtained from wheat, bread and other products made from flour in human life is far too great. Wheat is a strategic product that is widely grown in the world, plays an important role in the nutrition and commercial life of many countries, is the most produced among crops and is used in human nutrition (Arısoy and Oğuz 2005).

In terms of world wheat production, China (133.6 million tons) ranks first. This country is followed by India (103.6 million tons), Russia (74.5 million tons) and USA (52.3 million tons). Turkey, on the other hand, ranks 11th in world wheat production with a production of 19 million tons (Anonymous 2019). It has an agricultural area of approximately 23 million ha in Turkey. Wheat is produced in approximately 7 million hectares of this area. Konya province ranks first in Turkey in terms of cultivation area (6.2 million dec-

\footnotetext{
* Corresponding author email: mkaraca@selcuk.edu.tr

**This study is a part of first authors MS thesis
}

ares) and production (1.92 million tons) (Anonymous 2020).

Today world population is increasing rapidly. Uncontrolled population growth is the most important fact gradually revealing the danger of hunger. Population growth increasing every day causes wheat yield to fall short. One of the most significant agricultural factors restricting wheat production is weeds because weeds cause decreases in the quality of wheat crop, and they also reduce yield of wheat produced in unit area. Weeds are the natural plants of agricultural and nonagricultural areas. Economically weeds mean, they are the plants which appear in and out of cultivated areas and do more harm than good for cultivated plants.

Weeds compete with crop plants for water, nutrients, space and light. These factors sometimes act alone and sometimes together. Because of some characteristics, they often have superior competitive power against crop plants. If measures are not taken, weeds can cause $20-40 \%$ yield loss depending on the species of crop plants (Güncan 1982; Güncan and Karaca 2018; Zimdahl 2018; Güncan, 2019).

By contaminating with crop plant seeds, weed seeds decrease the nutritional value and spoil seed quality (Güncan 2002). In the research conducted in Turkey, it was determined that contamination rate of weed seeds 
in wheat product which was not passed through the selector was at an average of $1.17 \%$ numerically, at an average of $0.412 \%$ as weight (Güncan and Boyraz 2001). According to the findings, when wheat production in our country is accepted as 20 million tons, it is necessary to consider that 8.240 tons of weed seeds are consumed each year and sown again into the fields in case of not cleaning wheat product. The same researchers state that if the mentioned wheat is sown without cleaning, 5.600 weed seeds perdecare will be carried into the field just through the contaminated wheat seeds. In other words, 5-6 weed seeds per $\mathrm{m}^{2}$ are carried through the mentioned way and this might cause a significant level of weed contamination. Tursun et al (2006) reported that the most common weed seeds contaminated with wheat were Sinapis arvensis, Hordeum vulgare, Lolium temulentum, Boreava orientalis and G. tricornutum respectively, and $H$. vulgare, $B$. orientalis, $S$. arvensis, and L. temulentum by weight, respectively in Kahramanmaraş. Karaca and Güncan (2009), carried out a study to determine the contamination ratio of Secale cereale to wheat product. It was determined that wild rye seed was contaminated in wheat product with an average of $1.1536 \%$ numerically and $0.9522 \%$ by weight in Konya province.

Gökalp and Üremiş (2015) determined that the most common weed seeds contaminated numerically with wheat were Avena sterilis, S. arvensis and $G$. tricornutum and A. sterilis, Silybum marianum and Hordeum murinum by weight respectively in Mardin province. Baş et al. (2016), found that in their study to detect weed seeds contaminated with wheat crops, Agrostemma githago and Caucalis latifolia were numerically very dense. They found that Adonis sp., Ranunculus arvensis and G. tricornutum were heavily contaminated in the Eastern Black Sea Region. Pala et al. (2018) determined that the weed seeds were most intensely contaminated into the harvested wheat product belonged to the Poaceae family with 13 species. It was determined that the most common species were Avena fatua and A. sterilis in Diyarbakir province. In the research of Bozkurt and Tursun (2018) found that numerically, S. arvensis, Cephalaria syriaca and Polygonum aviculare were the most common weed seeds respectively. According to the weight ratio, the most common species were found as Caucalis daucoides, $C$. syriaca and Galium aparine in Muş province. In the studies conducted in Balıkesir and Çanakkale, $S$. arvensis and $G$. aparine were determined as the most frequently contaminated weed seeds numerically, while $H$. vulgare was the most contaminated species in both provinces by weight (Kaçan and Tursun 2019).

In a study conducted between the years of 1974 and 1990 in Germany, it was reported that weed seed contamination average rate of grains was $0.5 \%$, and this contamination increased to $2 \%$ in wheat (Fuchs and Voit, 1992). Similarly, in another study conducted in Spain, it was determined that weed seeds contaminated in grains dramatically (Trigo et al. 1991). Nikham et al. (2002) were carried out a survey in the Victoria in
Australia. Mainly wheat and barley seeds were collected. The main weed seeds in cereal samples were annual ryegrass (Lolium multiflorum), wild oats (Avena spp.), silver grass (Vulpia bromoides L.), lesser canary grass (Phalaris minor), brome grass (Bromus spp.) and paradoxa grass (Phalaris paradoxa).

Çetik (1985) reported that there are too many weeds growing in the cultivation areas of forage plants and in pasture-meadow areas in the Central Anatolia Region. The researcher stated that weed seeds quickly germinate under appropriate conditions, they might remain dormant for a long time under inappropriate conditions. It is stated that many of these weeds are eaten by animals. Güncan and Karaca (2018), on the other hand, states that some weeds are a good feed source for animals both in summer and winter, some of them are not eaten by animals when they are fresh in summer because of bitter substances that they contain, but when they are dried, their bitterness disappears and they are eaten hungrily by animals.

The aim of this study, to determine which weed species are contaminated with wheat by using the samples taken from under-sieve, purifier, washing and trieur parts in flour mill plants and the rate of contamination. It is known that weed seeds obtained from various sieve systems in flour mill plants are used as feed in animal husbandry in Turkey. However, a large number and species of weed seeds can be transported to agricultural fields with animal manures. No study has been found on this subject. Therefore, the species and intensities of weed seeds that can be transported to agricultural areas with animal manures will be revealed.

\section{Materials and Methods}

The material of this study conducted in 2012-2013 consists of weed seeds obtained from flour mill plants in Konya, weed seed collection, precision scale, binocular and diagnostic books.

\section{Determining weed seeds and their intensities:}

In the research, samples were taken from 15 flour mills with high operating capability in Konya province. These are the samples which were processed through different sieving systems such as sieve, purifier, washing and trieur parts of factory. Since the materials from which the seeds are obtained are of different weights and volumes, the samples were extracted from materials until $100 \mathrm{~g}$ of weed seeds were obtained per flour mill plant. One hundred grams of weed seeds obtained from each flour mill plant were separated according to their genus and species.

In the second phase of the research, weed seeds collected from samples were diagnosed. Following this process, weed seeds were counted by hand in the herbology laboratory and their weights were recorded after weighing on a precision scale. Besides, intensity (as number and weight) and frequency of occurrence were calculated for each weed seed in $1.500 \mathrm{~g}$ of sam- 
ples collected from 15 flour mill plants. In the research, $\%$ intensity (as number and weight) and frequency of occurrence were calculated according to the following formula (Odum 1971; Uludağ 1993; Baş et al .2016).

Intensity $(\%)=T / n x 100$

Frequency $(\%)=M / n x 100$

$\mathrm{T}=$ Total number of weed seed in the collected sample

$\mathrm{M}=$ Number of samples in which weed species was encountered

$\mathrm{n}=$ Number of samples

Weight $(\%)=A / B \times 100$

Number $(\%)=C / D x 100$

$\mathrm{A}=$ Weight of selected weed seed

$\mathrm{B}=$ Seed weight in total

$\mathrm{C}=$ Number of selected weed seed

$\mathrm{D}=$ Number of seeds in total

To name the weeds in Turkish, the book entitled “Türkiye'nin Yabancı Otları" by Uluğ et al (1993) and the dictionary entitled "Bitki Terimleri" by Akalın (1952) were used. For the morphological and biological characteristics of the plants, the book entitled "Türkiye'nin Çayır-Mera Bitkileri" was employed. While diagnosing weed seeds, the weed seed collection prepared in previous years by Academic Member Prof. Dr. Ahmet GÜNCAN from Selcuk University, Faculty of Agriculture, Department of Plant Protection was used.

Table 1

Number and weight of weed seeds determined from the wheat flour mill plants in Konya Provinces

\begin{tabular}{|c|c|c|}
\hline Weed Species/Families & Seed (number) & *Seed Weight $(\mathrm{g})$ \\
\hline \multicolumn{3}{|l|}{ Apiaceae (Umbelliferae) } \\
\hline Bifora radians Bieb. & 693 & 8.184 \\
\hline Bifora testiculata (L.) sprengex Schultes & 535 & 5.808 \\
\hline Caucalis daucoides $\mathrm{L}$. & 7 & 0.307 \\
\hline Caucalis latifolia $\mathrm{L}$. & 75 & 1.386 \\
\hline Caucalis orientalis & 6 & 0.002 \\
\hline Patroselinum sp. & 1 & 0.001 \\
\hline \multicolumn{3}{|l|}{ Asteraceae (Compositae) } \\
\hline Carthamus persicus Willd. & 91 & 0.18 \\
\hline Centaurea deprassa Bieb. & 560 & 6.359 \\
\hline Centaurea melitensis & 5 & 0.02 \\
\hline Centaurea repens $\mathrm{L}$. & 102 & 0.087 \\
\hline Centaurea solstitialis $\mathrm{L}$. & 2 & 0.005 \\
\hline Cirsium lanceolatum (L.) Scop. & 14 & 0.129 \\
\hline Onopordum acanthium L. & 350 & 2.274 \\
\hline Onopondum caucalis & 1 & 0.006 \\
\hline \multicolumn{3}{|l|}{ Boraginaceae } \\
\hline Anchusa italica Retz. & 36 & 0.807 \\
\hline Borogo sp. & 24 & 0.179 \\
\hline Lithospermum arvense $\mathrm{L}$. & 5.954 & 18.728 \\
\hline Lycopsis orientalis & 9 & 0.041 \\
\hline \multicolumn{3}{|l|}{ Brassicaceae (Cruciferae) } \\
\hline Boreava orientalis Jaub and Spach & 433 & 21.654 \\
\hline Euclidium syriacum (L.) R.Br. & 140 & 0.714 \\
\hline Neslia apiculata Fisch. & 872 & 4.142 \\
\hline Rapistrum rugosum (L.) All. & 966 & 7.952 \\
\hline Thilapsi arvense $\mathrm{L}$. & 4.737 & 4.46 \\
\hline \multicolumn{3}{|l|}{ Caryophyllaceae } \\
\hline Agrostemma githago $\mathrm{L}$. & 933 & 11.507 \\
\hline Gypsophila sp. & 23.689 & 58.836 \\
\hline Silene caucalis & 627 & 0.953 \\
\hline Silene conoidea $\mathrm{L}$. & 7.299 & 16.954 \\
\hline Vaccaria pyramidata Medik & 13.566 & 37.4 \\
\hline \multicolumn{3}{|l|}{ Chenopodiaceae } \\
\hline Beta lomatogona Fisch and Mey. & 31 & 0.247 \\
\hline Chenopodium sp. & 6.078 & 5.342 \\
\hline
\end{tabular}

In addition, Bischof's (1978) book entitled "Common Weeds from Iran, Turkey, the Near East and North Africa" on weed diagnosis was used. Weed seeds that could not be identified in the study were stated as others.

\section{Results and Discussion}

In the research, 79 weed species belonging to 19 families were determined and identified. Among these identified species, Fabaceae which included 15 species and Poaceae which included 12 species were the families which had the most species.

According to the results obtained in the research, the weed seed having the highest number was G. tricornutum (Fam: Rubiaceae) with the number of 39.539 P. aviculare and Polygonum convolvulus (Fam: Polygonaceae) follow this species with the numbers of 38.313 and 37.736 respectively. The fewest number of weed seed is 1 and it belongs to Trifolium alexandrinum, Medicago hispida, Medicago sativa, Nicis benedictus, Onopordum caucalis, Patroselinum sp. The heaviest weed seed was Aegilops cylindrica (Fam: Poaceae) with 289,077 g A. fatua (Fam: Poaceae) and $P$. convolvulus (Fam: Polygonaceae) follow it with $150,764 \mathrm{~g}$ and $133,449 \mathrm{~g}$ respectively. The weed seed having the lowest weight is Trifolium alexandrinum (Table 1). 
Table 1(Continue)

Number and weight of weed seeds determined from the wheat flour mill plants in Konya Provinces

\begin{tabular}{|c|c|c|}
\hline Convolvulaceae & & \\
\hline Convolvulus arvensis $\mathrm{L}$. & 9641 & 94.612 \\
\hline \multicolumn{3}{|l|}{ Dipsacaceae } \\
\hline Cephalaria aristata (C.) Koch & 682 & 2.962 \\
\hline Cephalaria syriaca (L.) Schrad. & 46 & 0.45 \\
\hline \multicolumn{3}{|l|}{ Fabaceae (Leguminosae) } \\
\hline Lathyrus aphaca $\mathrm{L}$. & 67 & 0.893 \\
\hline Lathyrus sp. & 213 & 0.429 \\
\hline Medicago hispida Gaertn. & 1 & 0.038 \\
\hline Medicago rigidula (L.) All. & 3 & 0.155 \\
\hline Medicago sativa $\mathrm{L}$. & 1 & ${ }^{* *} 0$ \\
\hline Melilotus officinalis (L.) Desr. & 2.627 & 4.626 \\
\hline Onobrichis sativa Lam. & 4 & 0.47 \\
\hline Trifolium alexandrinum & 1 & ${ }^{* *} 0$ \\
\hline Vicia fabae & 37 & 4.669 \\
\hline Vicia pannonica & 495 & 21.7 \\
\hline Vicia peregrina $\mathrm{L}$. & 8 & 0.226 \\
\hline Vicia sativa $\mathrm{L}$. & 246 & 14.355 \\
\hline Vicia villosa Roth. & 60 & 1.433 \\
\hline \multicolumn{3}{|l|}{ Labiatae (Lamiaceae) } \\
\hline Marrubium peregrinum & 298 & 0.426 \\
\hline Salvia sclarea $\mathrm{L}$. & 24 & 0.077 \\
\hline \multicolumn{3}{|l|}{ Lilliaceae } \\
\hline Allium sp. & 8 & 0.038 \\
\hline Ornithogalum narbonense $\mathrm{L}$. & 5 & 0.039 \\
\hline \multicolumn{3}{|l|}{ Malvaceae } \\
\hline Althaea sp. & 14 & 0.97 \\
\hline Malva parviflora $\mathrm{L}$. & 6 & 0.048 \\
\hline \multicolumn{3}{|l|}{ Poaceae (Gramineae) } \\
\hline Aegilops cylindrica Host. & 6.997 & 289.077 \\
\hline Alopecurus myosuroides Huds. & 221 & 0.358 \\
\hline Avena fatua $\mathrm{L}$. & 7.050 & 150.764 \\
\hline Avena sativa & 1.354 & 32.3 \\
\hline Avena sterilis ssp. Ludoviciana & 29 & 0.363 \\
\hline Lolium multiflorum Lam. & 1.335 & 7.539 \\
\hline Lolium temulentum $\mathrm{L}$. & 847 & 7.694 \\
\hline Panicum italicum & 3.244 & 13.023 \\
\hline Phalaris minor Retz. & 4.890 & 11.112 \\
\hline Poa bulbosa L. & 560 & 1.121 \\
\hline Secale cereale $\mathrm{L}$. & 2.535 & 95.892 \\
\hline Setaria lutescens (Weigel ex Stuntz) F. T. Hubbard & 4.058 & 12.791 \\
\hline Sorghum halepense (L.) Pers. & 38 & 0.144 \\
\hline Sorghum sp. & 193 & 3.797 \\
\hline \multicolumn{3}{|l|}{ Polygonaceae } \\
\hline Polygonum aviculare $\mathrm{L}$. & 38.313 & 91.329 \\
\hline Polygonum convolvulus $\mathrm{L}$. & 37.736 & 133.449 \\
\hline Rumex crispus $\mathrm{L}$. & 96 & 0.125 \\
\hline \multicolumn{3}{|l|}{ Ranunculaceae } \\
\hline Adonis aestivalis $\mathrm{L}$. & 4 & 0.039 \\
\hline Adonis flammea Jacq. & 3 & 0.019 \\
\hline Consalida orientalis (Gay) Schröd. & 1.264 & 1.587 \\
\hline Ranunculus arvensis $\mathrm{L}$. & 499 & 6.064 \\
\hline \multicolumn{3}{|l|}{ Resedaceae } \\
\hline Reseda lutea $\mathrm{L}$. & 2.894 & 2.968 \\
\hline \multicolumn{3}{|l|}{ Rubiaceae } \\
\hline Galium aparine $\mathrm{L}$. & 7.885 & 24.8 \\
\hline Galium tricornutum Dandy. & 39.539 & 111.679 \\
\hline \multicolumn{3}{|l|}{ Scrophulariaceae } \\
\hline Veronica triphyllos $\mathrm{L}$. & 391 & 0.436 \\
\hline \multicolumn{3}{|l|}{ Solanaceae } \\
\hline Hyoscyamus niger L. & 238 & 0.226 \\
\hline \multicolumn{3}{|l|}{ Diğer } \\
\hline Nicis benedictus & 1 & 0.025 \\
\hline Others & 39.475 & 140.024 \\
\hline TOTAL & 284.025 & 1.500 \\
\hline
\end{tabular}

** Quite close to 0

When Table 2 is examined, numerically the most intensive species according to the \% calculations were G. tricornutum with $16.17 \%$, P. aviculare with 15.67 $\%$ and Polygonum concolvulus with $15.43 \%$ respec- tively. While A. cylindrica had the highest intensity with $21.22 \%$ as weight, $A$. fatua with $11.07 \%$ and $P$. convolvulus with $9.80 \%$ followed them. When frequency of occurrence is taken in to consideration, it is 
seen that Convolvulus arvensis with the rate of $100 \%$ was present in all samples. This species was followed by Lithospermum arvense, Gysophila sp., P. aviculare, $S$. cereale and Vaccaria pyramidata with the rate of $93,33 \%$.

Table 2

Number (\%), weight (\%) and frequency (\%) of weed seeds obtained from the wheat flour mill plants in Konya Province

\begin{tabular}{|c|c|c|c|}
\hline Weed Species & Seed Number (\%) & Seed Weight (\%) & Frequency $(\%)$ \\
\hline Adonis aestivalis & 0.0016 & 0.0028 & 13.3333 \\
\hline Adonis flammea & 0.0012 & 0.0266 & 13.3333 \\
\hline Aegilops cylindrica & 2.8613 & 21.2244 & 86.6666 \\
\hline Agrostemma githago & 0.3815 & 0.8448 & 33.3333 \\
\hline Allium sp. & 0.0032 & 0.0026 & 13.3333 \\
\hline Alopecurus myosuroides & 0.0903 & 0.0262 & 46.6666 \\
\hline Althaea sp. & 0.0057 & 0.0071 & 6.6666 \\
\hline Anchusa italica & 0.0147 & 0.0592 & 33.3333 \\
\hline Avena fatua & 2.8829 & 11.0693 & 86.6666 \\
\hline Avena sativa & 0.5536 & 2.3715 & 73.3333 \\
\hline Avena sterilis ssp. Ludoviciana & 0.0081 & 0.0266 & 13.3333 \\
\hline Beta lomatogona & 0.0126 & 0.8158 & 20 \\
\hline Bifora radians & 0.2833 & 0.6008 & 53.3333 \\
\hline Bifora testiculata & 0.2187 & 0.4264 & 13.3333 \\
\hline Boreava orientalis & 0.1770 & 1.5898 & 53.3333 \\
\hline Borogo sp. & 0.0098 & 0.0131 & 6.6666 \\
\hline Carthamus persicus & 0.0372 & 0.0132 & 40 \\
\hline Caucalis daucoides & 0.0028 & 0.0254 & 33.3333 \\
\hline Caucalis latifolia & 0.0306 & 0.1017 & 60 \\
\hline Caucalis orientalis & 0.0024 & 0.0001 & 6.6666 \\
\hline Centaurea deprassa & 0.2290 & 0.4668 & 86.6666 \\
\hline Centaurea melitensis & 0.0020 & 0.0014 & 13.3333 \\
\hline Centaurea repens & 0.0417 & 0.0651 & 66.6666 \\
\hline Centaurea solstitialis & 0.0008 & 0.0003 & 6.6666 \\
\hline Cephalaria aristata & 0.2788 & 0.2174 & 40 \\
\hline Cephalaria syriaca & 0.0188 & 0.0330 & 26.6666 \\
\hline Chenopodium sp. & 2.4855 & 0.3922 & 53.3333 \\
\hline Cirsium lanceolatum & 0.0057 & 0.0094 & 40 \\
\hline Consalida arientalis & 0.5168 & 0.1165 & 80 \\
\hline Convolvulus arvensis & 3.9425 & 6.9465 & 100 \\
\hline Euclidium syriacum & 0.0572 & 0.0524 & 66.6666 \\
\hline Galium aparine & 3.224 & 1.8212 & 53.3333 \\
\hline Galium tricornutum & 16.1689 & 8.1996 & 86.6666 \\
\hline Gypsophila sp. & 9.6872 & 4.3198 & 93.3333 \\
\hline Hyoscomus niger & 0.0973 & 0.0195 & 26.6666 \\
\hline Lathyrus aphaca & 0.0273 & 0.0655 & 46.6666 \\
\hline Lathyrus sp. & 0.0053 & 0.0314 & 6.6666 \\
\hline Lithospermum arvense & 2.4348 & 1.3750 & 93.3333 \\
\hline Lolium multiflorum & 0.5459 & 0.5535 & 80 \\
\hline Lolium temulentum & 0.3463 & 0.5649 & 46.6666 \\
\hline Lycopsis arientalis & 0.0036 & 0.0030 & 33.3333 \\
\hline Malva parviflora & 0.0024 & 0.0035 & 13.3333 \\
\hline Marrubium peregrinum & 0.1218 & 0.0312 & 60 \\
\hline Medicago hispida & 0.0004 & 0.0027 & 6.6666 \\
\hline Melilotus officinalis & 1.0742 & 0.3396 & 73.3333 \\
\hline Medicago rigidula & 0.0012 & 0.0113 & 20 \\
\hline Medicago sativa & 0.0004 & 0 & 6.6666 \\
\hline Neslia apiculata & 0.3565 & 0.3041 & 80 \\
\hline Nicis benedictus & 0.0004 & 0.0018 & 6.6666 \\
\hline Onobrichis sativa & 0.0016 & 0.0034 & 26.6666 \\
\hline Onopordum acanthium & 0.1431 & 0.1669 & 73.3333 \\
\hline Onopordum caucalis & 0.0004 & 0.0004 & 6.6666 \\
\hline Ornithogalum narbonense & 0.0020 & 0.0028 & 6.6666 \\
\hline Panicum italicum & 1.3265 & 0.9461 & 53.3333 \\
\hline Patroselium sp. & 0.0004 & ${ }^{*} 0$ & 6.6666 \\
\hline Phalaris minor & 1.996 & 0.8158 & 86.6666 \\
\hline Poa bulbosa & 0.2290 & 0.0823 & 66.6666 \\
\hline Polygonum aviculare & 15.6675 & 6.7055 & 93.3333 \\
\hline Polygonum convolvulus & 15.4316 & 9.7980 & 73.3333 \\
\hline Ranunculus arvensis & 0.2040 & 0.4452 & 60 \\
\hline Rapistrum rugosum & 0.3950 & 0.5838 & 80 \\
\hline Reseda lutea & 1.1834 & 0.2179 & 86.6666 \\
\hline Rumex crispus & 0.0392 & 0.0091 & 46.6666 \\
\hline
\end{tabular}

Similarly, Tursun et al. (2006), Gökalp and Üremiş (2015) and Baş et al. (2016) found G. tricornutum and A. sterilis as the most contaminated species the wheat crop in their studies. Also Bozkurt and Tursun (2018) found that numerically, $P$. aviculare were the most common weed seeds respectively. 
Table 2 (Continue)

Number $(\%)$, weight $(\%)$ and frequency $(\%)$ of weed seeds obtained from the wheat flour mill plants in Konya Province

\begin{tabular}{|c|c|c|c|}
\hline Salvia sclarea & 0.0098 & 0.0056 & 33.3333 \\
\hline Secale cereale & 1.0366 & 7.0405 & 93.3333 \\
\hline Setaria lutescens & 1.6594 & 0.9391 & 53.3333 \\
\hline Silene caucalis & 0.2564 & 0.0699 & 6.6666 \\
\hline Silene conoidea & 2.9848 & 1.2447 & 86.6666 \\
\hline Sorghum halepense & 0.0155 & 0.0105 & 26.6666 \\
\hline Sorghum sp. & 0.0789 & 0.2787 & 13.3333 \\
\hline Thilapsi arvense & 1.9371 & 0.3274 & 66.6666 \\
\hline Trifolium alexandrinum & 0.0004 & ${ }^{*} 0$ & 6.6666 \\
\hline Vaccaria pyramidata & 5.5476 & 2.7464 & 93.3333 \\
\hline Veronica triphyllos & 0.1598 & 0.0320 & 26.6666 \\
\hline Vicia fabae & 0.0151 & 0.3428 & 6.6666 \\
\hline Vicia pannonica & 0.2024 & 1.5981 & 33.3333 \\
\hline Vicia peregrina & 0.0032 & 0.0165 & 6.6666 \\
\hline Vicia sativa & 0.1005 & 1.0539 & 26.6666 \\
\hline Vicia villosa & 0.0245 & 0.1052 & 13.3333 \\
\hline TOTAL & 99.9145 & 99.9722 & \\
\hline \multicolumn{4}{|l|}{ * Quite close to 0} \\
\hline \multicolumn{4}{|c|}{ Intensity (Numerically) } \\
\hline 0,06 & & \multicolumn{2}{|c|}{$\begin{array}{l}\text { Frequency of Occurrence: } \\
\qquad 50 \%<\text { very frequer }\end{array}$} \\
\hline $0.02-0$ & & \multicolumn{2}{|c|}{$\begin{array}{l}50 \% \leq \text { very frequent } \\
25-50 \% \text { frequent }\end{array}$} \\
\hline $0.01-0$ & & \multicolumn{2}{|c|}{$10-25 \%$ quite frequent } \\
\hline $0.01 \%$ & & \multicolumn{2}{|c|}{$10 \% \geq$ rarely encountered weed seeds } \\
\hline
\end{tabular}

In his study conducted in Van, Tepe (1998) determined that $S$. cereale took place on the top in terms of weight and numerical contamination. In our study, the mentioned species ranked among the top five and its frequency of occurrence was found as $93,3333 \%$. Also Karaca and Güncan (2009), determined that $S$. cereale seed was contaminated in wheat product with an average of $1.1536 \%$ numerically and $0.9522 \%$ by weight in Konya province.

Once again, in their study including the West of Anatolia, Güncan and Boyraz (2001) reported the species intensively contaminated in wheat as $S$. cereale, Vicia spp., G. aparine and G. tricornutum. In our study, G. tricornutum took place on the top numerically and ranked forth as weight. S. cereale also had a considerable percentage in terms of weight and frequency of occurrence.

Similarly, in their study conducted in Samsun, Mennan and Iş1k (2003) determined that G. aparine took place on the top in terms of intensity, Tursun et al. (2006) determined that $G$. tricornutum ranked fifth. Also Kaçan and Tursun (2019) were determined $G$. aparine as the most frequently contaminated weed seeds numerically in wheat crop.

Among the species determined as a result of the study, A. aestivalis, A. flammea, A. githago, Chenopodium sp., C. syriaca, C. aristata, Cirsium lanceolatum, $H$. niger L. temulentum, L. multiflorum and V. pyramidata have been reported to be toxic to humans and animals in different literature (Watt et al. 1962; Muzik (1970); Seçmen and Leblebici 1987; Picon et al. 1991; Suter 2002; Wagstaff 2008; Anonymous 2021).

\section{Conclusion}

It can reduce the contamination of weed seeds in wheat product to minimum by taking some measures such as; using pure seeds, passing through a selector, performing cultural and chemical control in the weedy fields. Today in Turkey, many weed seeds continue to

contaminate in wheat product and maintain their development because of the reasons mentioned above. Definitely, in order to prevent this situation, it is our responsibility to raise the awareness of our farmers, to avoid incorrect agricultural practices being applied and to take necessary measures and to put them into practice.

Wheat is purchased from the Central Anatolia and outside region of the flour mill plants in Konya. As a result of the study, the detection of species with different ecological demands such as Alopecurus myosuroides, A. sterilis, Bifora testculata, C. syriaca and Sorghum halepense shows this result. Thus, different species of weeds enter the region. Weed seeds from flour mill plants are also fed to animals as forage. There is a risk of contamination of animal manures and thus agricultural lands due to climate change. In addition, weed species that are not in the region can be transported to the agricultural lands of the region with the use of animal manure. Therefore, weed seeds obtained from flour mill plants should not be fed to animals as forage. Or it should be aged for at least 6 months. Also, toxic species such as Lolium spp., Chenopodium sp., Cephalaria spp., Adonis spp., A. githago, Hyoscyamus niger, $V$. pyramidata present in weed seeds can harm animal health. The alkaloids contained in these toxic weeds can cause reactions and threaten human and animal health.

On the other hand, highly contaminating species are known as major weeds in farmlands. The species such as palmer amaranth (Amaranthus palmeri) are often reported to be herbicide-resistant and have been increasing in recent years worldwide (Gaines et al. 2010). Herbicide resistant weed seeds have been reported as contaminants in commercial grains (Michael et al. 2010; Shimono et al. 2010). The international grain 
trade is also a major pathway of introduction because various weed seeds contaminate grain commodities (Hulme 2009; Asai et al. 2007; Shimono and Konuma, 2008; Michael et al. 2010; Asav and Kadıoğlu 2014; Wilson et al. 2016).

With the increasing wheat import, weed seeds contaminated with wheat enter the country. The weed that adapts to a region can reach the economic thresholds level within a few years. In this way, a weed that was not previously found in the country may appear as a problem in the future.

\section{References}

Akalın Ş (1952). Büyük bitkiler kılavuzu, Ankara.

Anonim (2020). Bitkisel Üretim. https://biruni.tuik.gov.tr/medas/?kn=92\&locale=tr (Date of access: 15.06.2021)

Anonymous (2019). Crop Production Data. http://www.fao.org/faostat/en/\#data/QC (Date of access: 15.06.2021)

Anonymous (2021). Zehirli Yabanc1 Otlar. http://www.turkiyeherboloji.org.tr/otlar.asp?tur=6. (Date accessed: 28.05.2021).

Arısoy H, Oğuz C (2005). Tarımsal araştırma enstitüleri tarafından yeni geliştirilen buğday çeşitlerinin tarım işletmelerinde kullanım düzeyi ve geleneksel çeşitler ile karşılaştırmalı ekonomik analizi: Konya ili örneği. Yüksek lisans tezi, Selçuk Üniversitesi, Fen Bilimleri Enstitüsü, Konya.

Asai M, Kurokawa S, Shimizu N, Enomoto T (2007). Exotic weed seeds detected from imported small cereal grains into Japan during 1990's. Journal of Weed Science Technology 52:1-10.

Asav Ü, Kadıŏlu İ (2014). Rusya Federasyonu'ndan Türkiye'ye İthal Edilmek Üzere Trabzon Limanı' na Gelen Buğdaylardaki Yabancı Ot Tohumlarının Belirlenmesi. Iğdır Univ. Journal of Institu Science \& Technology. 4(4): 29-36, 2014.

Bischof F (1978). Common weeds from Iran, Turkey, the near east and north Africa. GTZ, DağHarmanrskjöld Weg I.D-6326, Eschborn I, 212, Germany.

Bozkurt M Tursun N (2018). Muş İlinde Buğday Ürününe Karışan Yabancı Ot Tohumları. Turk Journal of Weed Science 21(2):1-15.

Baş A, Karaca M, Güncan A (2016). Doğu Karadeniz Bölgesi'nde buğday ürününe karışan yabancı ot tohumlarının tespiti ve dağılışları. Turkish Journal of Weed Science 19(2): 49-60.

Fuchs H, Voit B (1992). Purity and contamination in cereal seed samples-long term survey from result of seed testing, Bayerisches Landwirtschaftliches Jahrbuch 69, p. 757-777.

Gaines TA, Zhang W, Wang D, Bukun B, Chisholm ST, Shaner DL, Nissen SJ, Patzoldt WL, Tranel PJ, Culpepper AS, Grey TL, Webster TM, Vencill WK,
Douglas Sammons R, Jiang J, Preston C, Leach JE, Westra P. (2010) Gene amplification confers glyphosate resistance in Amaranthus palmeri. PNAS 107:1029-1034

Gökalp Ö, Üremiş İ (2015). Mardin buğday ekim alanlarında bulunan yabanc1 ot türlerinin, yaygınlıklar1nın ve yoğunluklarının belirlenmesi. Mustafa Kemal Üniversitesi Ziraat Fakültesi Dergisi 20 (1): 13-22.

Güncan A (1982). Erzurum yöresinde buğday ürününe karışan bazı yabancı ot tohumlarının çimlenme biyolojisi üzerinde araştırmalar. Atatürk Üniversitesi, Ziraat Fakültesi Yayın No: 270, Erzurum.

Güncan A, Boyraz N (2001). Anadolu'nun batısında buğday ürününe karışan yabancı ot tohumları ve yoğunlukları, Selçuk Üniversitesi Ziraat Fakültesi Dergisi 15(26), 161-172.

Güncan A (2002). Anadolu'nun doğusunda buğday ürününe karışan yabancı ot tohumları, bunların yoğunlukları. Konya Ticaret Borsası Dergisi 5(11): 36-41.

Güncan A (2019). Yabancı Otlar ve Mücadele Prensipleri. Güncellenmiş ve ilaveli 7. Baskı. Akıncı Ofset Matbaa. 269 s. ISBN: 9786056915611

Güncan A, Karaca M (2018). Yabanc1 Ot Mücadelesi. Güncellenmiş ve ilaveli 4. Baskı. Selçuk Üniversitesi Basımevi. 334 s. ISBN: 9754481784.

Hulme PE (2009). Trade, transport and trouble: managing invasive species pathways in an era of globalization. Journal of Applied Ecology 46:10-18.

Ikeda M, Nishi T, Asai M, Muranaka T, Konuma A, Tominaga T, Shimono Y (2021). The Role of Weed Seed Contamination in Grain Commodities as Propagule Pressure. Biological Invasions. 17 p. DOI: https://doi.org/10.21203/rs.3.rs-220124/v1

Kaçan K, Tursun N (2019). Balıkesir ve Çanakkale İllerinde Buğday Ürünü İçerisine Karışan Yabancı Ot Tohumlarının Belirlenmesi. KSÜ Tarım ve Doğa Dergisi 22(2): 248-259.

Karaca M, Güncan A (2009). Yabani Çavdar'ın (Secale cereale L. L.) bazı biyolojik özellikleri ve Konya ilinde buğday ürününe karışma oranının belirlenmesi, Türkiye III. Bitki Koruma Kongresi, Van.

Mennan H, Işık D (2003). Buğday tohumluğunda bulunan yabancı ot tohumlarının yoğunlukları ve bitkiye dönüşüm oranlarının saptanması, Türkiye Herboloji Dergisi 6(1): 8-15.

Michael PJ, Owen MJ, Powles SB (2010). Herbicideresistant weed seeds contaminate grain sown in the Western Australian grainbelt. Weed Science 58:466-472

Muzik T (1970). Weed Biyology and Control. McGraw, Hill Book Company, Toronto.

Niknam SR, Moerkerk M and Cousens R (2002). Weed seed contamination in cereal and pulse crops. 13th Australian Weeds Conference: papers \& procee- 
dings: weeds, threats now, \& forever? 8-13 September 2002, 59-62.

Odum EP (1971). Fundamentals of Ecology. W. B. Saunders Company, Philadeiphia, London, Toronto, $574 \mathrm{p}$.

Pala F, Mennan H, Çı̆̆ F, Dilman H (2018). Diyarbakır'da buğday ürününe karışan yabancı ot tohumlarının belirlenmesi. Turkish Journal of Agricultural Research 5(3):183-190.

Picon SJ, Blanco Carmona JG, Garces Sotilis MD. (1991). Occupational asthma caused by vetch ( $\mathrm{Vi}$ cia sativa). The Journal of Allergy and Clinical Immunolgy 88(1):135-136.

Seçmen Ö, Leblebici E, (1987). Yurdumuzun Zehirli Bitkileri. Ege Üniversitesi Fen Fakültesi Baskı İşleri, $102 \mathrm{~s}$, Bornova-İzmir.

Shimono Y, Konuma A (2008). Effects of humanmediated processes on weed species composition in internationally traded grain commodities. Weed Research 48:10-18.

Shimono Y, Takiguchi Y, Konuma A (2010). Contamination of internationally traded wheat by herbicide resistant Lolium rigidum. Weed Biol Management 10:219-228.

Suter R.J (2002). Suspected cyanide poisoning in cows fed vetch (Vicia sativa) hay. Australian Veterinary Journal 80(5): 282.

Tepe I (1998). Van'da buğday ürününe karışan yabancı ot tohumlarının yoğunluk ve dağılımları, Türkiye Herboloji Dergisi 1(2): 1-13.
Trigo MM, Bootello ML, Cabeduzo B (1991). Contribution to a knowledge of the weeds of cereals in andalusia: structure of dispersal. Proceedings of the 1991 Meeting of the Spanish Weed Science, Society, Madrid, Spain.

Tursun N, Kantarc1 Z, Seyithanoğlu M (2006). Kahramanmaraş'ta buğday ürününe karışan yabancı ot tohumlarının belirlenmesi. KSÜ, Fen ve Mühendislik Dergisi 9(2): 110-115.

Uludağ A (1993). Diyarbakır ve yöresinde buğday, mercimek kültürlerindeki önemli yabancı otların dağılışı ve bunların biyolojik özellikleri üzerinde araştırmalar. Yüksek Lisans Tezi, Cumhuriyet Üniversitesi, Fen Bilimleri Enstitüsü, Tokat.

Uluğ E, Kadıoğlu İ, Üremiş İ, (1993). Türkiye'nin yabancı otları ve bazı özellikleri, Tarım ve Köyişleri Bakanlığı, Zirai Mücadele Enstitüsü Müdürlüğü, Yayın No:78, Adana, 513.

Wagstaff DJ (2008). International Poisonous Plant Checklist: An Evidence-Based Reference. CRC Press. Taylor \& Franchis Group. 464s.

Watt JM, Gerdina M, Brandwijk B (1962). Medicinal and Poisonous Plants of Southern and Eastern Africa. E. and S. Livinstone LTD. London 173-75 and 475-477.

Wilson CE, Castro KL, Thurston GB, Sissons A (2016) Pathway risk analysis of weed seeds in imported grain: a Canadian perspective. NeoBiota 30:49-74

Zimdahl RL (2018). Fundamentals of Weed Science, 5th Edition, Academic Press, 758p. 